\title{
Biomass-density patterns in the temperate seagrass Zostera marina
}

\author{
Birgit Olesen, Kaj Sand-Jensen* \\ Department of Plant Ecology, University of Aarhus, Nordlandsvej 68, DK-8240 Risskov, Denmark
}

\begin{abstract}
Extensive studies of biomass-density patterns have led to formulation of general allometric theories for terrestrial plant populations. Similar universal patterns have not been studied in the rhizomatous, clonal marine seagrasses despite their worldwide distribution in monospecific stands and their suitability in comparative studies. We analyzed biomass-density relationships for 29 eelgrass populations distributed between $30^{\circ}$ and $56^{\circ} \mathrm{N}$ in Europe, USA and Japan. The maximum leaf biomass was independent of shoot density among populations and conformed to the law of 'constant final yield per unit area' The maximum total plant biomass of eelgrass, including the rhizomes and roots in the sea bottom, increased with shoot density. The leaf biomass - shoot density combinations within different eelgrass stands approximated a cyclic seasonal pattern similar to that of terrestrial clonal plants with continuous shoot formation. Most eelgrass populations predominantly allocated biomass to increased shoot size and maintained stable shoot density. However, severe disturbance that reduced leaf biomass and opened the canopy prior to spring growth enhanced the growth and survival of new small shoots. Self-thinning, expressed as a net decline of shoot density at maximum summer biomass, was a relatively unpronounced phenomenon within natural eelgrass stands because the period of high biomass was short before optimal growth conditions vanished. Despite the constant shoot density, however, there was continuous shoot turnover in eelgrass stands. The natural eelgrass stands did not conform to the description of self-thinning or the $-3 / 2$ power law observed for even-aged terrestrial populations undergoing density-dependent mortality. Biomass-density patterns are, nevertheless, informative descriptors of demography and disturbance of seagrass species.
\end{abstract}

KEY WORDS: Zostera marina Population structure $\cdot$ Maximum biomass - Thinning rule

\section{INTRODUCTION}

Plant biomass per unit area is the product of shoot density and mean shoot weight and, therefore, changes with the numerical size of these parameters. The interdependence of shoot weight and shoot density has been examined experimentally in many evenaged terrestrial plant populations. The common finding has been that the populations start to self-thin (i.e. shoot density drops) as the plants grow in size and biomass. Logarithmic plots of mean weight versus shoot density for self-thinning populations show a $-3 / 2$ slope (Yoda et al. 1963, White \& Harper 1970). Obviously,

- Present address: Freshwater Biological Laboratory, University of Copenhagen, Helsingørsgade 51, DK-3400 Hillerød, Denmark plant biomass cannot increase indefinitely and the slope will eventually approach -1 (White \& Harper 1970) such that biomass per unit area remains constant and independent of shoot density.

Determinations of the thinning slope through linear regression analysis have been associated with methodological and statistical difficulties (Weller 1987, LaBarbera 1989). One main objection is the autocorrelation created when mean shoot weight, calculated as biomass divided by density, is plotted as a function of density. To prevent this problem, biomass rather than mean shoot weight should be regressed to shoot density yielding a slope of $-1 / 2$ for populations conforming to the $-3 / 2$ rule. Reanalysis of data used in support of the thinning law has revealed considerable variability among plant stands and the existence of an ideal thinning slope has been questioned (Zeide 1985, Weller 
1987, Lonsdale 1990). Some deviations from the $-1 / 2$ slope in biomass-density plots may, however, be systematic and have been attributed to species differences in growth allometry (White 1981) and growth in low light conditions where the relationship between plant biomass and density is more likely to follow a zero slope (Lonsdale \& Watkinson 1982). Moreover, many clonal plants do not conform to the thinning rule (Hutchings 1979, Harnett \& Bazzaz 1985) although density and shoot weight may be limited by an upper boundary line (Hutchings 1979). The physiological connections among shoots within the clone may prevent density-dependent mortality (Hutchings \& Mogie 1990).

It is a common finding (White 1977, Mohler et al. 1978, Blake et al. 1991, Osawa \& Allen 1993), and a keystone in the allometric hypothesis of Long \& Smith (1984), that leaf mass per unit area remains constant whereas total biomass increases in older stands as the $1 / 2$ power of declining shoot density because of increasing stem and necrobiomass. This finding is important for aquatic plants which display substantial and systematic differences in the proportions of leaf mass per total plant biomass among species of different growth form and habitats (Madsen 1991). The variable leaf proportions may account for the $-3 / 2$ exponent in mean weight-density relationships among different species of freshwater and marine macrophytes (Duarte \& Kalff 1987).

Most seagrass species have a clonal perennial growth, and form large monospecific stands (Tomlinson 1974). Temporal and spatial patterns of plant biomass and density in natural populations are, therefore, relatively easy to study. Comparisons are possible both within species and among the small pioneer and the large climax species of seagrasses. However, sufficient data for comparisons are as yet only available for eelgrass Zostera marina L.

Eelgrass is widespread in temperate areas throughout the northern hemisphere (den Hartog 1970) and has been the subject of many studies of biomass, shoot density and production (e.g. Sand-Jensen 1975, Jacobs 1979, Robertson \& Mann 1984, Roman \& Able 1988). Nevertheless, few researchers have evaluated the universality of their findings and nobody has examined the biomass-density patterns in the context of the theories advanced for terrestrial plants.
We examined the temporal patterns of leaf biomass and shoot density based on data for 29 populations distributed worldwide to test (1) if universal biomassdensity patterns existed; (2) if perturbations influenced the patterns; and (3) if self-thinning occurred at peak biomass. We then examined the global biomassdensity patterns for both the leaf and the total plant biomass (including the below-ground rhizomes and roots) to test (4) if eelgrass conforms to patterns observed in even-aged terrestrial populations undergoing self-thinning.

\section{MATERIALS AND METHODS}

Zostera marina morphology and demography. Perennial eelgrass populations grow by the iterative production of modules that consist of a segmented horizontal rhizome with a leaf and 2 associated root bundles from each node (Tomlinson 1974). The leaves form the above-ground biomass and the rhizomes and roots the below-ground biomass. The branching rhizome system may remain intact for 1 to $2 \mathrm{yr}$ before the oldest parts decay and connections to lateral daughter shoots disintegrate. We use the term shoot (= leaf shoot) for each cluster of leaves supported by a single basal meristem. The leaf biomass - shoot density patterns presented are, therefore, equivalent to leaf shoot bio-

Table 1. Zostera marina. Location, disturbance mentioned and number of eelgrass stands $(n)$ described in the compiled data sets of seasonal variation in biomass and shoot density

\begin{tabular}{|c|c|c|c|}
\hline Location & $\mathrm{n}$ & Disturbance & Source \\
\hline Denmark & $\begin{array}{l}1 \\
1 \\
1 \\
7 \\
1\end{array}$ & Ice scour & $\begin{array}{l}\text { Sand-Jensen (1975) } \\
\text { Wium-Andersen \& Borum (1984) } \\
\text { Pedersen (1990) } \\
\text { Hedal (1992) } \\
\text { Olesen \& Sand-Jensen (1994) }{ }^{\text {a }}\end{array}$ \\
\hline The Netherlands & 1 & & Nienhuis \& De Bree (1980) \\
\hline France & 1 & & Jacobs (1979) \\
\hline Canada & 1 & Ice scour & Robertson \& Mann (1984) \\
\hline Eastern USA & $\begin{array}{l}1 \\
3\end{array}$ & $\begin{array}{l}\text { High temp. } \\
\left(>25^{\circ} \mathrm{C}\right) \\
\text { High temp. } \\
\left(>25^{\circ} \mathrm{C}\right)\end{array}$ & $\begin{array}{l}\text { Wetzel \& Penhale (1983) } \\
\text { Heck \& Thoman (1984) } \\
\text { Orth \& Moore (1986) } \\
\text { Roman \& Able (1988) }\end{array}$ \\
\hline Western USA & $\begin{array}{l}2 \\
1\end{array}$ & & $\begin{array}{l}\text { Kentula \& McIntire (1986) } \\
\text { Thom }(1990)\end{array}$ \\
\hline Mexico & 1 & & Ibarra-Obando (1989) \\
\hline Japan & 4 & & Aioi (1980) \\
\hline
\end{tabular}


mass - leaf shoot density relationships. A terminal and several lateral leaf shoots may belong to the same rhizome chain, thus making total shoot weight, including rhizomes and roots, an irrelevant term.

Each eelgrass leaf is formed in synchrony with a rhizome segment and every node has a potentially branch-producing meristem. Shoot density may, therefore, remain relatively constant despite pulses of shoot natality and mortality that lead to pronounced size differences among the shoots (Olesen \& Sand-Jensen 1994). The pronounced size differences among shoots are yet another reason for preferring analysis of biomass-shoot density patterns to mean shoot weight - shoot density relationships.

Data analysis. From the literature, we compiled data on seasonal changes in leaf biomass, rhizomeroot biomass and shoot density of 29 different eelgrass populations examined in shallow water at locations ranging in latitude from 30 to $56^{\circ} \mathrm{N}$ in North America, Europe and Japan (Table 1). Only those investigations with frequent measurements (intervals of 1 to $2 \mathrm{mo}$ ) during a year were included, making it likely that annual maxima and minima can be determined with sufficient confidence. Registration of major events of perturbations to the populations, resulting in pronounced biomass reductions, are included in Table 1

We analyzed the relationship of leaf, rhizome-root, and total biomass to shoot density at maximum biomass during summer for those populations where this information was available. The seasonal variation of eelgrass leaf biomass was estimated as maximum biomass divided by minimum biomass. The contribution of shoot weight and shoot density to maximum biomass development was evaluated by comparing the ratios of mean shoot weight and shoot density at the time of maximum and minimum biomass. To evaluate if leaf biomass during the winter minimum influenced eelgrass branching frequency, the relative increase of shoot density was calculated between winter minimum and the time of maximum density during biomass increase. However, the calculated ratios only reveal net changes as biomass is lost from the populations due to a continuous leaf turnover and shoot mortality. Also, the continuous formation of new shoots on side branches (Olesen \& Sand-Jensen 1994) may balance shoot mortality and thereby reduce the observed net changes in shoot density despite a large flux of shoots.

Biomass dynamics during the annual cycle were evaluated from trajectories of logarithmic relationships between eelgrass leaf biomass and shoot density as they change with time. A general tendency across populations was obtained by resolving biomassdensity combinations for each population into 4 distinct periods describing biomass dynamics during periods of 2 to 3 mo prior to and after the summer maximum as well as the winter minimum (viz. Fig. 4). Because peak summer biomass is earlier at low latitudes than at high latitudes, we used the internal timing in the populations rather than a strict division by months. For each period a grid was established in the graphic plane defined by leaf biomass and shoot density. The size of each grid represents a doubling of both leaf biomass and shoot density. Trajectories of biomass and shoot density were then averaged for all populations passing through each grid. This average trajectory for each grid is represented by a vector of equal length but variable direction. The range of vectors therefore describes the mean direction of biomass and density development for all possible biomass-density combinations observed in the data set.

\section{RESULTS}

The included eelgrass populations displayed similar annual patterns in leaf biomass with minimum values occurring during late autumn and winter and maximum values during summer (Table 2).

The maximum leaf biomass during summer was relatively uniform among the different eelgrass populations; $80 \%$ of the values were in the range 111 to $391 \mathrm{~g}$ DW $\mathrm{m}^{-2}$ (10 to $90 \%$ fractiles) and the median value was $245 \mathrm{~g} \mathrm{DW} \mathrm{m}^{-2}$. Shoot density at the time of maximum biomass was more variable among populations (257 to 2193 shoots $\mathrm{m}^{-2}, 10$ to $90 \%$ fractiles) (Table 2 ). Hence, the among-population coefficient of variation for leaf biomass ( $C V=44 \%$ ) was smaller than that for shoot density $(\mathrm{CV}=68 \%)$. The maximum total plant

Table 2. Zostera marina. Eelgrass leaf and total plant biomass, leaf shoot density and mean shoot weight at the winter minimum and the summer maximum. Values are given as the median and 10-90\% fractiles (in parentheses) of all populations examined. $n$ : number of observations

\begin{tabular}{|c|c|c|c|c|}
\hline & Winter & $\mathrm{n}$ & Summer & $\mathrm{n}$ \\
\hline $\begin{array}{l}\text { Leaf biomass } \\
\left(\mathrm{g} \mathrm{DW} \mathrm{m} \mathrm{m}^{-2}\right)\end{array}$ & $\begin{array}{c}31 \\
(5-82)\end{array}$ & 32 & $\begin{array}{c}245 \\
(111-391)\end{array}$ & 40 \\
\hline 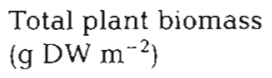 & $\begin{array}{c}98 \\
(19-170)\end{array}$ & 24 & $\begin{array}{c}354 \\
(150-538)\end{array}$ & 25 \\
\hline $\begin{array}{l}\text { Shoot density } \\
\text { (shoots } \mathrm{m}^{-2} \text { ) }\end{array}$ & $\begin{array}{c}604 \\
(143-2069)\end{array}$ & 24 & $\begin{array}{c}905 \\
(257-2193)\end{array}$ & 32 \\
\hline $\begin{array}{l}\text { Mean shoot weight } \\
\left(\mathrm{mg} \text { DW shoot }{ }^{-1}\right)\end{array}$ & $\begin{array}{c}37 \\
(16-188)\end{array}$ & 24 & $\begin{array}{c}273 \\
(76-924)\end{array}$ & 32 \\
\hline
\end{tabular}


biomass had a median value of $354 \mathrm{~g} \mathrm{DW} \mathrm{m}^{-2}$ among populations ( 150 to $538 \mathrm{~g} \mathrm{DW} \mathrm{m}^{-2}, 10$ to $90 \%$ fractiles).

The leaf biomass (= leaf shoot biomass) showed an 8.4-fold (median values) increase from the winter minimum to the summer maximum (Fig. 1). Shoot density (= leaf shoot density), on the other hand, only showed a 1.5-fold increase and, thus, the extent of seasonal biomass variability was more the result of changing shoot weight than shoot density (Fig. 1). The maximum leaf biomass in the different populations during summer was independent of shoot density $\left(\mathrm{r}^{2}=0.033\right.$;

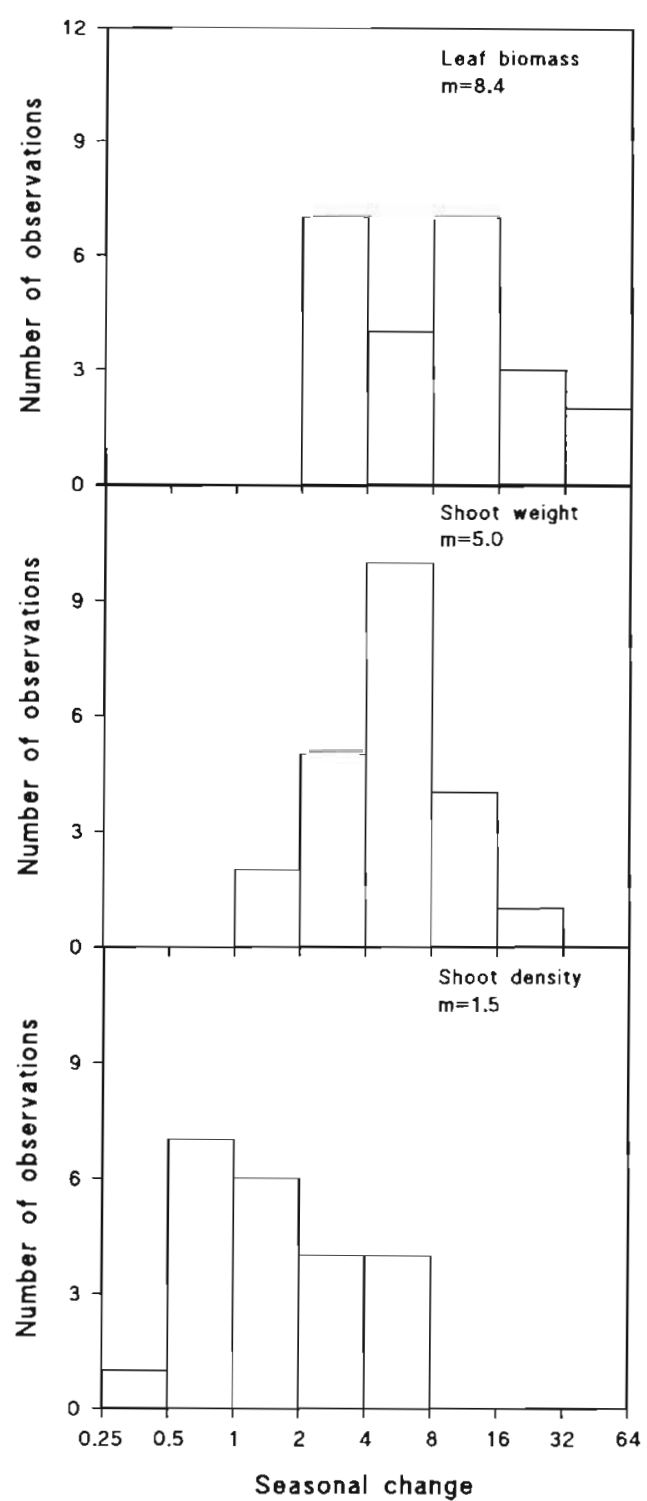

Fig. 1. Zostera marina. Frequency distribution of the extent of seasonal changes in leaf biomass, mean shoot weight and shoot density calculated as the ratio between values at time of summer maximum and winter minimum. The distribution is based on data from 22 eelgrass populations ( $\mathrm{m}=$ median ratio)
Fig. 2). Mean shoot weight and shoot density at maximum biomass will, therefore, follow a slope close to -1 in a logarithmic plot (disregarding the autocorrelation problems). The slope calculated here by a geometric mean (GM) linear regression (Ricker 1973) between eelgrass leaf biomass and shoot density was $-1.05 \pm$ $0.19(95 \% \mathrm{CL})\left(\mathrm{r}^{2}=0.75\right)$.

The maximum rhizome-root biomass during summer in the different populations increased as a function of shoot density with the slope of $1.08 \pm 0.33$ (95\% CL) $\left(r^{2}=0.55\right)$ in logarithmic scales (Fig. 2). The total plant biomass was also a positive function of shoot density [slope $0.68 \pm 0.24(95 \% \mathrm{CL}) ; \mathrm{r}^{2}=0.40$ ] .

Trajectories of monthly measurements of leaf biomass and shoot density from 8 different populations

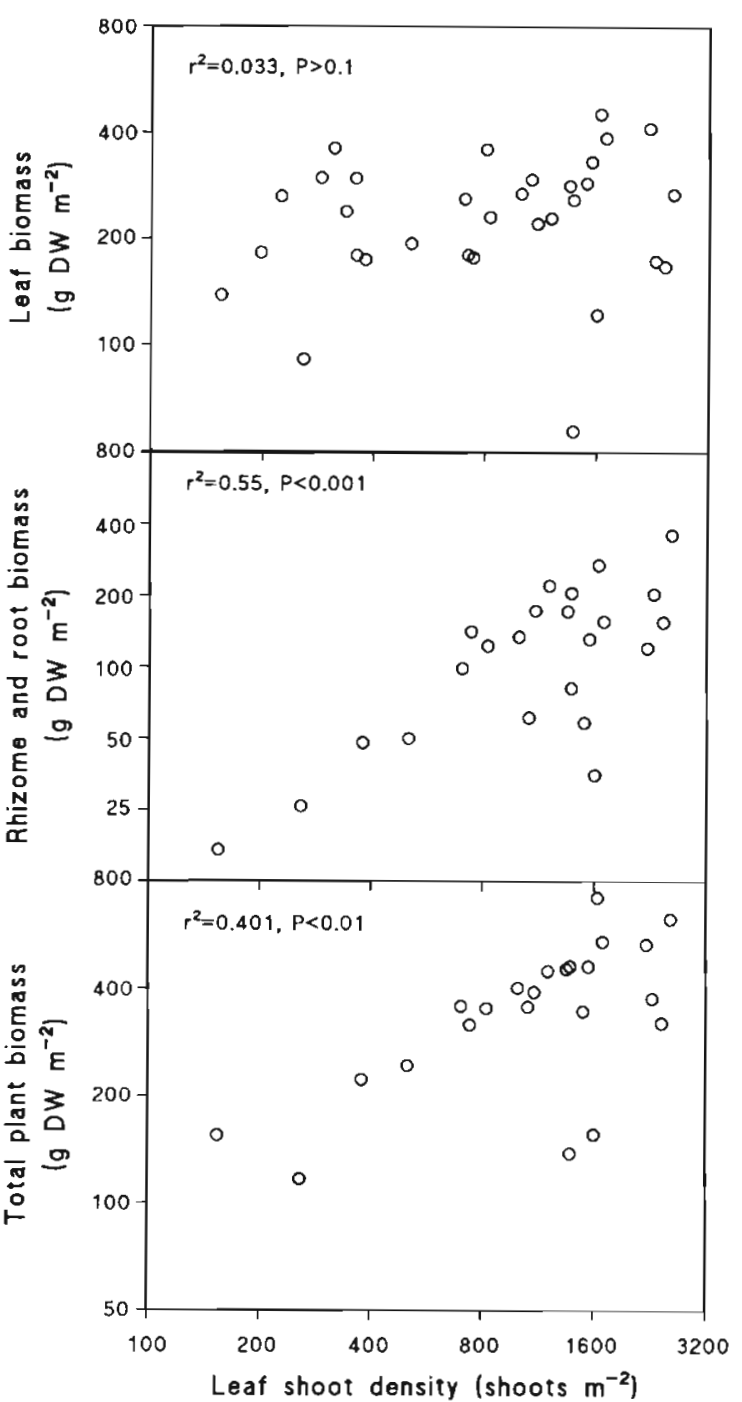

Fig. 2. Zostera marina. Leaf biomass, rhizome-root biomass and total plant biomass as a function of shoot density for shallow-water populations at the time of maximum biomass 
are shown in logarithmic plots in Fig. 3. For populations with vertical trajectories, leaf biomass development largely depends on changes in shoot size, and horizontal trajectories indicate constant biomass despite changes in shoot density. In most $(90 \%)$ of all the examined populations, shoot density was higher ( 3 to $2900 \%$ ) in early spring than late in autumn. During midsummer density declined in $30 \%$ of the populations, when maximum biomass was approached. However, the greatest decline in shoot density occurred during late summer and autumn, coinciding with the initial biomass decline. The unperturbed populations from Limfjorden (Denmark), France and Nova Scotia (Canada) predominantly changed seasonally in mean shoot weight, and shoot density was much less variable. In eelgrass stands experiencing very low biomass in early spring, following a particularly harsh winter with ice scouring (Øresund, Denmark 1978/79) or dieback in late summer caused by high temperatures (Chesapeake Bay, Virginia, USA), shoot density continued to increase from spring throughout early summer (Fig. 3). Overall, the total biomass-shoot density patterns (not shown) resembled those for leaf biomass - shoot density (Fig. 3) but biomass levels were, of course, higher and the influence of shoot density on total biomass was stronger (viz. Fig. 2).

Populations experiencing low biomass in early spring displayed a net increase in shoot density during the first months of biomass development, whereas higher biomass levels in early spring resulted in only minor increases in shoot density (Fig. 4A). Thus, the initial increase in shoot density is significantly related to the biomass level prior to seasonal expansive growth $\left(\mathrm{r}^{2}=0.58\right.$, $p<0.001$ ) (Fig. 5). During the time interval ( 2 to $3 \mathrm{mo}$ ) up to maximum summer biomass, most populations with biomasses exceeding the global median value among populations $(245 \mathrm{~g} \mathrm{DW}$ $\mathrm{m}^{-2}$ ) showed a small net decline in shoot density (Fig. 4B). However, some populations never reached such high biomasses, as seasonal growth ceased
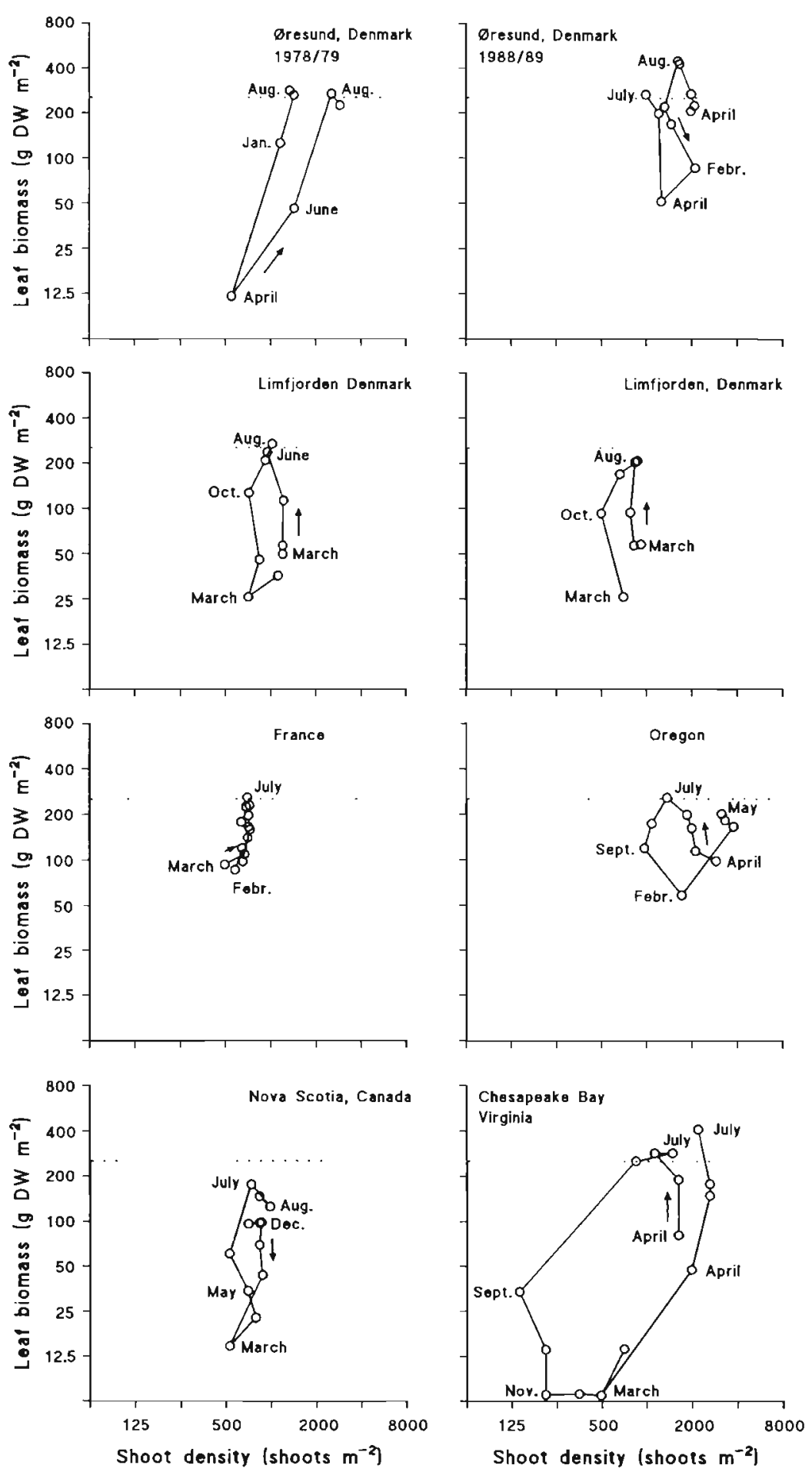

Fig. 3. Zostera marina. Relationship between leaf biomass and shoot density through time for 8 selected eelgrass populations from Øresund 1978/79 (Wium-Andersen \& Borum 1984) and 1988/89 (Pedersen 1990), Limfjorden (Olesen \& Sand-Jensen 1993), France (Jacobs 1979), Oregon (Roman \& Able 1988). Nova Scotia (Robertson \& Mann 1984) and Chesapeake Bay (Orth \& Moore 1986). Arrows indicate the direction of the trajectories during seasonal biomass development. $(. .$.$) median value of peak leaf biomass during sum-$ mer for all examined eelgrass populations 


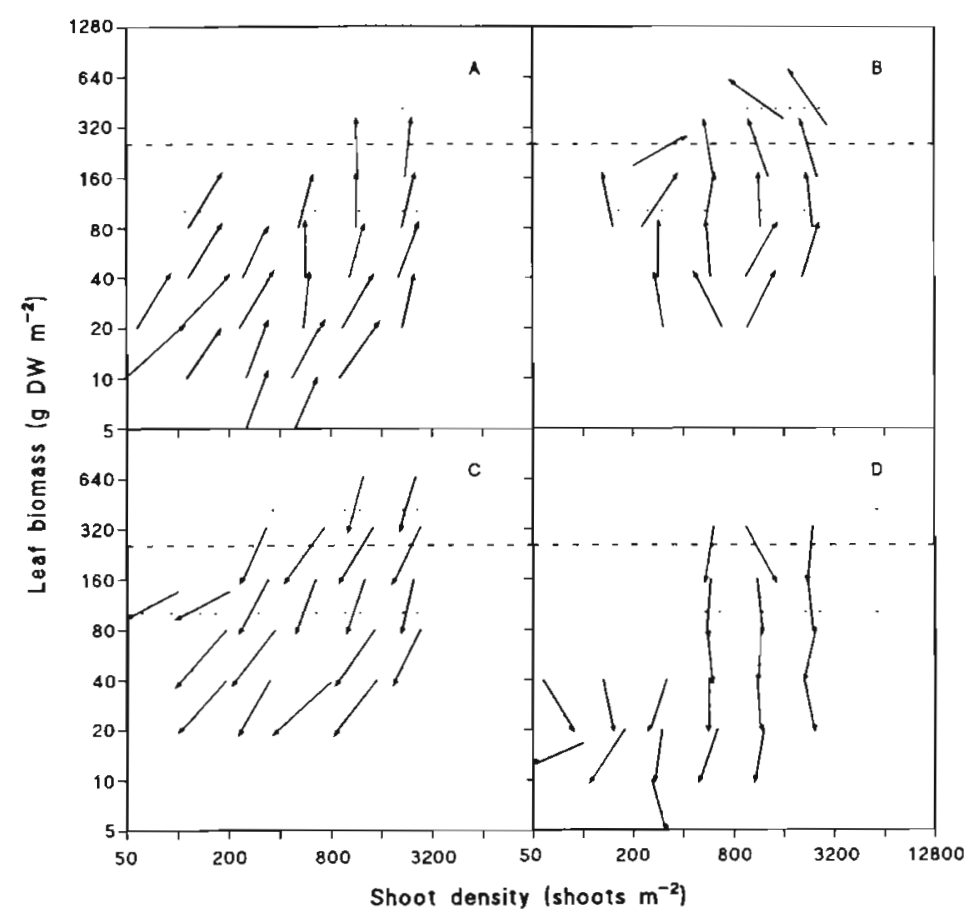

Fig. 4. Zostera marina. Combinations of leaf biomass and shoot density for all included eelgrass populations $(n=29)(A)$ from the period of minimum biomass and 2 to 3 mo after, (B) for 2 to 3 mo before and until the maximum biomass is achieved, (C) from the biomass peak and 2 to 3 mo after and (D) during the winter period until the time of minimum biomass. Arrows mark the average direction of the trajectories of biomass-density combinations through time and are based on 1 to 12 individual trajectories passing through each grid with a size corresponding to a doubling of biomass and density. Horizontal lines show the median value (-.-) and $10-90 \%$ fractiles $(\cdots)$ of maximum leaf biomass for all examined populations

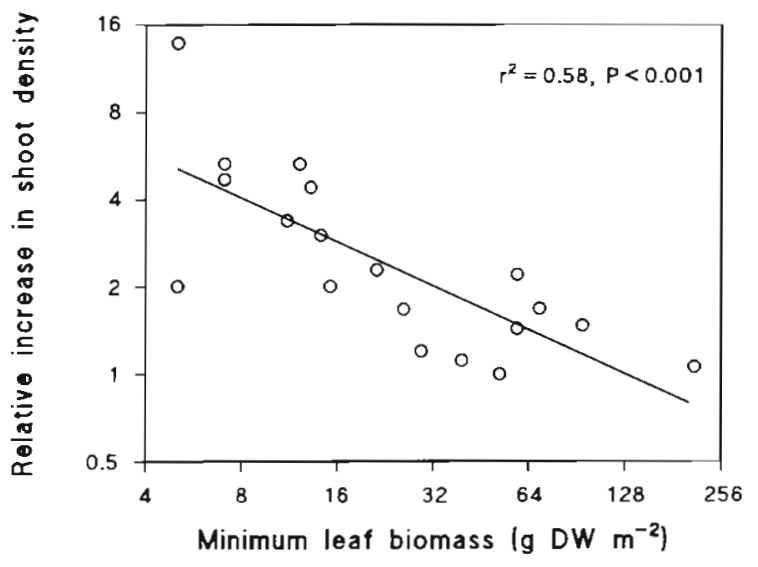

Fig. 5. Zostera marina. Relative increase in eelgrass shoot density during seasonal biomass increase shown as a function of the initial minimum leaf biomass. The relative increase is calculated as maximum shoot density obtained between minimum and maximum leaf biomass divided by the shoot density at minimum biomass, e.g. the value 1.0 corresponds to no net change in shoot density before this level was attained. In those instances shoot density mostly continued to increase or remained constant. Immediately following the time of maximum biomass, the biomass declined through a reduction of shoot density as well as shoot weight (Fig. 4C), whereas the subsequent biomass decline during winter occurred mainly due to a reduction of shoot weight (Fig. 4D).

\section{DISCUSSION}

\section{Maximum leaf biomass and shoot density}

The maximum leaf biomass achieved by individual eelgrass stands during midsummer was relatively uniform and only populations approaching or exceeding the global median summer biomass showed a net decline in shoot density (Fig. 4B). Previous analyses of size-density relationships have mostly been applied to greenhouse experiments of even-aged individuals (White \& Harper 1970). These plants increase in mean weight with time and only minor shoot mortality occurs until the populations reach the thinning line. For growth under field conditions, however, climatic and other environmental conditions may constrain production and increase biomass losses, depending on time and site. Thus, in several eelgrass populations maximum biomass was achieved without any apparent density-dependent mortality, expressed as a net decline in shoot density, or populations never reached the possible thinning line before biomass growth had already ceased and light and temperature started to decline at the end of the optimal growing season (Fig. 4B).

Seasonal constraints to biomass development have also been observed for perennial herbs on land, where the highest rates of shoot mortality were associated with seasonal declining temperature and precipitation (Cyperus esculentus L.; Lapham \& Drennan 1987) and with reduced light availability (Mercurialis perrenis L.; Hutchings 1979). Furthermore, environments characterized by frequent disturbances may prevent biomass development up to an ultimate thinning line as described for a sand dune annual [Vulpia fasciculata (Forskål) Samp.], where density-independent shoot mortality was caused by wind exposure and by rabbit grazing (Watkinson \& Harper 1978).

The growth form of eelgrass resembles that of terrestrial clonal plants, with a phalanx growth strategy with lateral shoots formed close to the main terminal 
shoot (Schmid \& Harper 1985). Such plant types may avoid shoot mortality invoked by crowding by regulating the recruitment of new shoots (Lovett Doust 1981, Schmid \& Harper 1985, de Kroon \& Schieving 1990). When seasonal biomass variability is encountered it is expected to occur predominantly via changes in shoot size. This pattern was observed in eelgrass populations growing in stable environments (Fig. 3 and Olesen \& Sand-Jensen 1994), and may also be expected for other seagrass species that develop dense stands composed of large shoots with slow lateral growth. Pioneer species, on the other hand, tend to have high production of new shoots, and the shoot density seems more to be regulated by a subsequent shoot mortality caused by crowding than by reduced recruitment rates (Lovett Doust 1981, Schmid \& Harper 1985). Small seagrass species that form many new shoots on side branches during the growing season (Duarte 1991) may adopt the same strategy when occupying new areas. Hence, eelgrass populations subject to severe reductions in biomass prior to the onset of growth, and a subsequent biomass expansion predominantly through extensive shoot recruitment, are likely to experience self-thinning if large summer biomasses are subsequently achieved. Annual eelgrass populations may behave similarly if many seedlings become established and develop a dense cover, but evidence to support this suggestion is not available.

The logarithmic relationship between leaf biomass and shoot density among the many eelgrass populations at the time of peak biomass followed a zero slope conforming to the law of constant final leaf mass per unit area (Harper 1977). Eelgrass populations with the leaf biomass close to this upper boundary line (median value $245 \mathrm{~g} \mathrm{DW} \mathrm{m}^{-2}$ ) are expected to undergo densitydependent growth, constrained by the availability of light. Applying the measured light attenuation coefficient for eelgrass populations $\left(0.0143 \mathrm{ln}_{\mathrm{ln}}\right.$ uts $\mathrm{g}^{-1}$ leaf DW $\mathrm{m}^{-2}$; Wium-Andersen \& Borum 1984), light transmission should be about $3.0 \%$ through $245 \mathrm{~g} \mathrm{DW} \mathrm{m}^{-2}$ and only $0.37 \%$ through $391 \mathrm{~g} \mathrm{DW} \mathrm{m}^{-2}$ (the $90 \%$ fractile of leaf biomass). New shoots being formed below a canopy of $245 \mathrm{~g} \mathrm{DW} \mathrm{m}^{-2}$ in shallow populations would only receive about 1 to 2 mol photons $\mathrm{m}^{-2} \mathrm{~d}^{-1}$ during July, which is close to the experimentally determined light compensation point for growth of eelgrass (Olesen \& Sand-Jensen 1993).

The zero slope relationship between leaf biomass and shoot density described for eelgrass stands is also found in self-thinning terrestrial populations displaying an exponent of $-1 / 2$ for the total plant biomass (Osawa \& Allen 1993). The rhizome-root biomass and total plant biomass of eelgrass, however, showed a positive relationship to shoot density, implying that space occupation did not limit biomass development of below-ground biomass. This finding demonstrates that leaf biomass is under much closer density-dependent control than stem and root biomass, so that more shoots predominantly lead to increased total biomass by greater allocation to stems or rhizomes whose maintenance is energetically less costly than the leaves.

A variable proportion of structural biomass among plant species may also contribute to the observed $-3 / 2$ power relationship of mean shoot weight and shoot density in comparisons among different species of submerged freshwater and marine macrophytes (Duarte \& Kalff 1987). Hence, this relationship does not necessarily support the existence of self-thinning, which is a process occurring among neighbour plants within populations. The allometric relationship indicates that species with large shoot size may have a disproportionately greater density and biomass, perhaps due to larger necrobiomass, greater longevity and smaller maintenance costs as implied in similar observations for terrestrial plants (Weller 1987).

\section{Seasonal biomass dynamics}

The trajectories of leaf biomass - shoot density combinations of eelgrass during a year followed a more or less cyclic relationship, as described for perennial populations of land plants with clonal architecture and overlapping shoot generations (Hutchings 1979). The terrestrial populations exhibited relatively constant biomass-density combinations among years, presumably due to predictable growth environments. The relationship between eelgrass leaf biomass and shoot density during the annual cycle, however, varied considerably among sites (Fig. 3). The increase of leaf biomass towards summer at most sites was largely due to increased shoot size and in some populations shoot density even declined (Figs. $1 \& 4$ ). However, low leaf biomass prior to extension growth during early spring induced the development of increased shoot density (Figs. 4 \& 5). Accordingly, the trajectories revealed 2 main patterns of seasonal biomass variability in a continuum of biomass density combinations, probably determined by the perturbation regimes.

For populations growing in stable habitats (Fig. 3; Limfjorden, Denmark) without major events of ice scour, high summer temperatures and strong wave exposure, the biomass increase was largely attributable to increased shoot weight, as shoot density changed only little during the year and biomassdensity combinations were similar between the 2 years. Maintenance of the Limfjord populations is mainly attributable to shoot recruitment through sustained branching, with main pulses of emergence 
during early summer and a gradual decline coinciding with increased self-shading within the vegetation (Olesen \& Sand-Jensen 1994). Mortality was high among the vegetative shoots that had overwintered and this was accompanied by growth of the new shoots recruited during summer. Accordingly, shoot density of eelgrass may remain approximately constant despite extensive shoot turnover, because shoot mortality is offset by shoot recruitment resulting from branching of the rhizomes. Severe inter-shoot competition and thinning may, therefore, presumably not be observed for such a clonal plant in nondynamic biomass-density diagrammes before the developmental cycle is completed, except for a short summer period where the populations approach the maximum sustainable biomass and shoot mortality exceeds the rate of shoot formation.

Eelgrass populations subject to major disturbances, on the other hand, may experience a low biomass prior to extensive biomass growth in spring. This situation probably results in growth and survival of new shoots that would otherwise have been suppressed. This was observed for populations growing in Øresund, Denmark in 1979/80 (Fig. 3), where a low leaf biomass in spring after a strong ice-winter with most rhizomes surviving resulted in a subsequent 4 -fold increase in shoot density during the growing season. At the same location after a mild winter (Øresund, Denmark 1989/90) a decline in shoot density was observed between late spring and late summer. Likewise, shallow-water populations in Chesapeake Bay (Fig. 3) experienced severe die-back at high temperatures during late summer, and shoot density subsequently increased during winter and spring (partly from seeds), emphasizing that the leaf biomass influences the balance between shoot formation and mortality (Fig. 5). Thus, eelgrass populations may display a wide range of growth strategies due to variable resource allocation to larger leaves in the shoots or branching and expansion of the rhizome and formation of many new shoots.

In conclusion, self-thinning expressed as a net decline in shoot density during the period of maximum biomass was a relatively unpronounced phenomenon within natural stands of eelgrass, because the period of high leaf biomass was relatively short or was never reached before light availability again dropped markedly. However, the observed independence of shoot density and maximum leaf biomass among populations did indicate the existence of an upper boundary to the attainable leaf biomass. The total plant biomass, including the belowground rhizomes and roots, on the other hand, was a positive function of shoot density. The dynamics of seasonal leaf biomass development in different eelgrass stands approximated a cyclic pattern of biomass-density combinations similar to that of terrestrial clonal plants with continuous shoot formation (Hutchings 1979). The variability in biomass-density combinations was high among the many studied populations, and the biomass allocation patterns observed in this study indicate that eelgrass is capable of altering its growth form in response to environmental conditions. Populations experiencing low frequencies of disturbance predominantly allocated biomass to increased shoot size and maintained stable population shoot density. In contrast, severe reductions in leaf biomass prior to the onset of growth enhanced light availability and the survival of new shoots, thereby contributing to the recovery of the populations following major disturbances.

Acknowledgements. This work was supported by grants from Limfjords Kommiteen and The Danish Natural Science Research Council (grant no. 11-7795). We thank J. Borum, C. M. Duarte, S. Markager and J. White for helpful discussions and improvements of the manuscript and Duarte \& Kalff (1987) for providing the initial ideas.

\section{LITERATURE CITED}

Aioi, K. (1980). Seasonal change in the standing crop of eelgrass (Zostera manina L.) in Odawa Bay, central Japan. Aquat. Bot. 8: 343-354

Blake, J., Somers, G., Ruark, G. (1991). Estimating limiting foliar biomass in conifer plantations from allometric relationships and self-thinning behaviour. For. Sci. 37: 296-307

de Kroon, H., Schieving, F. (1990). Resource partitioning in relation to clonal growth strategy. In: van Groenendael, J., de Kroon, $\mathrm{H}$. (eds.) Clonal growth in plants: regulation and function. SPB Academic Publishing, The Hague, p. $113-130$

den Hartog, C. (1970). The sea-grasses of the world. NorthHolland Publishing Company, Amsterdam

Duarte, C. M. (1991). Allometric scaling of seagrass form and productivity. Mar. Ecol. Prog. Ser. 77: 289-300

Duarte, C. M., Kalff, J. (1987). Weight-density relationships in submerged macrophytes. Oecologia 72: 612-617

Harnett, D. C., Bazzaz, D. C. (1985). The regulation of leaf, ramet and genet densities in experimental populations of the rhizomatous perennial Solidago canadensis. J. Ecol. 73: $429-443$

Harper, J. L. (1977). Population biology of plants. Academic Press, London

Heck, L. K., Thoman, T. A. (1984). The nursery role of seagrass meadows in the upper and lower reaches of the Chesapeake Bay. Estuaries 7: 70-92

Hedal, S. (1992). Bundvegetation i de indre dele af Roskilde Fjord og Isefjord. Miljøkontoret, Roskilde Amt

Hutchings, M. J. (1979). Weight-density relationships in ramet populations of clonal perennial herbs, with special reference to the $-3 / 2$ power law. J. Ecol. 67: 21-33

Hutchings, M. J., Mogie, M. (1990). The spatial structure of clonal plants: control and consequences. In: van Groenendael, J., de Kroon, H. (eds.) Clonal growth in plants: regulation and function. SPB Academic Publishing, The Hague, p. 57-76 
Ibarra-Obando, S. E. (1989). Las praderas de pastos marinos del Pacífico Mexicano con énfasis en Zostera marina L. In: Rosa-Vélez, J. de la, González-Farias, F. (eds.) Temas de oceanografía biológica en México. Univ. Autónoma de Baja California, Ensenada, p. 1-20

Jacobs, R. P. W. M. (1979). Distribution and aspects of the production and biomass of eelgrass, Zostera marina L., at Roscoff, France. Aquat. Bot. 7: 151-172

Kentula, M. E., McIntire, C. D. (1986). The autecology and production dynamics of eelgrass (Zostera marina L.) in Netarts Bay, Oregon. Estuaries 9: 188-199

LaBarbera, M. (1989). Analyzing body size as a factor in ecology and evolution. A. Rev. Ecol. Syst. 20: 97-117

Lapham, J., Drennan, D. S. H. (1987). Intraspecific regulation of populations of the clonal herb, Cyperus esculentus. J. appl. Ecol. 24: 1011-1024

Long, J. N., Smith, F. W. (1984). Relation between size and density in developing stands: a description and possible mechanisms. Forest Ecol. Mgmt 7: 191-206

Lonsdale, W. M. (1990). The self-thinning rule: dead or alive? Ecology 71: 1373-1388

Lonsdale, W. M., Watkinson, A. R. (1982). Light and self-thinning. New Phytol. 90: 431-445

Lovett Doust, L. (1981). Population dynamics and local specialization in a clonal perennial (Ranunculus repens). I. The dynamics of ramets in contrasting habitats. J. Ecol. 69: $743-755$

Madsen, D. M. (1991). Resource allocation at the individual plant level. Aquat. Bot. 41:67-86

Mohler, C. L., Marks, P. L., Sprugel, D. G. (1978). Stand structures and allometry of trees during self-thinning of pure stands. J. Ecol. 66: 599-614

Nienhuis, P. H., De Bree, B. H. H. (1980). Production and growth dynamics of eelgrass (Zostera marina) in brackish lake Grevelingen (The Netherlands). Neth. J. Sea Res. 14: $102-118$

Olesen, B., Sand-Jensen, K. (1993). Seasonal acclimatization of eelgrass Zostera marina growth to light. Mar. Ecol. Prog. Ser. 94: 91-99

Olesen, B., Sand-Jensen, K. (1994). Demography of shallow eelgrass (Zostera marina) populations: shoot dynamics and biomass development. J. Ecol. (in press)

Orth, R. J., Moore, K. A. (1986). Seasonal and year to year variations in the growth of Zostera marina L. (eelgrass) in the lower Chesapeake Bay. Aquat. Bot. 24: 335-341

Osawa, A., Allen, R. B. (1993). Allometric theory explains selfthinning relationships of mountain beech and red pine. Ecology 74: 1020-1032

This article was presented by G. W. Thayer (Senior Editorial Advisor), Beaufort, N. Carolina, USA
Pedersen, M. F. (1990). Nitrogen dynamics of eelgrass (Zostera marina L.). M.S. thesis, University of Copenhagen Ricker, W. E. (1973). Linear regression in fishery research. J. Fish. Res. Bd Can. 30: 409-434

Robertson, A. I., Mann, K. H. (1984). Disturbance by ice and life-history adaptations of the seagrass Zostera marina. Mar. Biol. 80: 131-141

Roman, C. T., Able, D. W. (1988). Production ecology of eelgrass (Zostera marina L.) in a Cape Cod salt marsh-estuarine system, Massachusetts. Aquat. Bot. 32: 353-363

Sand-Jensen, K. (1975). Biomass, net production and growth dynamics in an eelgrass (Zostera marina L.) population in Vellerup Vig, Denmark. Ophelia 14:185-201

Schmid, B., Harper, J. L. (1985). Clonal growth in grassland perennials. I. Density and pattern-dependent competition between plants with different growth forms. J. Ecol. 73: 793-808

Thom, R. M. (1990). Spatial and temporal patterns in plant standing stock and primary production in a temperate seagrass system. Botanica mar. 33: 497-510

Tomlinson, P. B. (1974). Vegetative morphology and meristem dependence -- the foundation of productivity in seagrasses. Aquaculture 4: 107-130

Watkinson, A. R., Harper, J. L. (1978). The demography of a sand dune annual: Vulpia fasciculata. 1 . The natural regulation of populations. J. Ecol. 66: 15-33

Weller, D. E. (1987). A reevaluation of the $-3 / 2$ power rule of plant self-thinning. Ecol. Monogr. 57: 22-43

Wetzel, R. L., Penhale, P. A. (1983). Production ecology of seagrass communities in the lower Chesapeake Bay. Mar. Technol. Soc. J. 17: 22-31

White, J. (1977). Generalization of self-thinning of plant populations. Nature 268: 373

White, J. (1981). The allometric interpretation of the self-thinning rule. J. theor. Biol. 89: 475-500

White, J., Harper, J. L. (1970). Correlated changes in plant size and number in plant populations. J. Ecol. 58: $467-485$

Wium-Andersen, S., Borum, J. (1984). Biomass variation and autotrophic production of an epiphyte-macrophyte community in a coastal Danish area: I. Eelgrass (Zostera marina L.) biomass and net production. Ophelia 23:33-46

Yoda, K., Kira, T., Ogawa, H., Huzumi, K. (1963). Self-thinning in overcrowded pure stands under cultivated and natural conditions. J. Biol. Osaka City Univ. Ser. D 14: $107-129$

Zeide, B. (1985). Tolerance and self-tolerance of trees. Forest Ecol. Mgmt 13: 149-166

Manuscript first received: July 1, 1993

Revised version accepted: March 11, 1994 